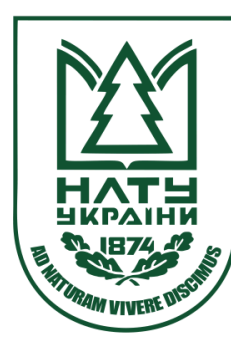

Науковий вісник НлТУ України Scientific Bulletin of UNFU http://nv.nltu.edu.ua

https://doi.org/10.15421/40280421

Article received $23.03 .2018 \mathrm{p}$.

Article accepted 26.04.2018 p.

O. V. Major

удК 336.221.4:330

Olga_major@ukr.net

Н. А. Свелеба, О. В. Майор

Львівський інститут економіки і туризму, м. Львів, Украйна

\title{
ПОДАТКОВІ ВАЖЕЛІ ВПЛИВУ НА ФОРМУВАННЯ ОРГАНІЗАЦІЙНО- ЕКОНОМІЧНОГО МЕХАНІЗМУ РОЗВИТКУ ПІДПРИЄМСТВ СФЕР ПОСЛУГ
}

Розглянуто організаційно-економічний механізм розвитку підприємств сфери послуг, виділено його складники. Виявлено основні підходи щодо організації оподаткування підприємств сфери послуг у контексті стимулювання їх розвитку, які потребують поглибленого вивчення та наукового обгрунтування чинних методик сплати податків у підприємницькій діяльності. Визначено основні завдання формування та реалізації організаційно-економічного механізму розвитку підприємств сфери послуг, серед яких: забезпечення якості надаваних послуг, поповнення бюджетів державного та місцевого рівнів, залучення зовнішніх інвестицій, підвищення попиту на послуги, збільшення зайнятості населення, та підвищення якості внутрішньої інфраструктури. Визначено, що складність оподаткування підприємництва в Україні організаційного характеру криється в необхідності витрачання значного часу на здійснення обліку, нарахування та сплату податків, проходження перевірок, здачу звітів. Запропоновано суб'єктам господарювання використання податкових важелів впливу на організаційноекономічний механізм підприємства. Серед таких важелів варто виокремити податкові інструменти, які передбачають оптимізацію кількості податків для підприємств сфери послуг, надання податкового кредиту, податкових пільг під конкретні проекти, які спрямовані на вирішення регіональних і соціальних проблем, розвитку соціального підприємництва, інвестування у діяльність, вибір альтернативних форм оподаткування (спрощеної), використання податкового менеджменту як засобу оптимізації податкових платежів (оптимізацію договірних відносин, застосування обгрунтованих і ефективних методик розподілу непрямих витрат, що дають змогу зменшити податкові платежі; розроблення системи контролю за наднормативними витратами, що не враховуються для оподаткування; податковий операційний моніторинг господарювання, діагностика витратної політики підприємства, податковий експрес-аналіз інноваційно-інвестиційних проектів).

Ключові слова: податки; системи оподаткування; податкове навантаження; податковий паспорт; оптимізація податкових зобов'язань; податковий моніторинг.

Вступ. Світовий досвід засвідчує, що основним елементом становлення постіндустріального суспільства $є$ сфера послуг. Дані теоретичних досліджень та практичний досвід переконливо стверджують, що сьогодні підприємства сфери послуг відіграють надзвичайно важливу роль в економіці, адже це найбільший сегмент підтримки глобального бізнесу, який сприяє не тільки створенню нових робочих місць та забезпеченню високого рівня зайнятості працездатного населення, але й створює умови для підвищення рівня життя та доходів громадян, активізації інноваційних і трансформаційних процесів.

Враховуючи значення підприємств сфери послуг для розвитку економіки, досить обгрунтованою має бути політика уряду, яка спрямована на створення сприятливих умов для розвитку, активізації та ефективного їх функціонування.

Аналіз останніх досліджень і публікацій. Питання формування організаційно-економічного механізму, ролі підприємництва у забезпеченні економічного зростання, його фінансової підтримки та оподаткування порушено у працях Г. Башняніна, 3. Варналія, Л. Воротіної, Б. Данилишина, Г. Козаченко, Ю. Лузана, В. Опарі- на, К. Павлюка, Ю. Сханурова, І. Жиляєва, К. Ляпіної, Є. Панченка, Р. Соболя, О. Титаренко, В. Черняка, О. Щура та ін.

Водночас сучасна практика податкового регулювання потребує комплексного дослідження фіскальних відносин між державою та суб'єктами бізнесу з приводу застосування різних схем оподаткування, визначення впливу різних податкових важелів, механізмів на підприємницьку активність, формування стратегічних напрямів податкової політики на основах фіскальної достатності, економічної ефективності та соціальної справедливості.

Мета дослідження. Визначити основні підходи щодо організації оподаткування підприємств сфери послуг у контексті стимулювання їх розвитку, які потребують поглибленого вивчення та наукового обгрунтування чинних методик сплати податків у підприємницькій діяльності.

Опис основного матеріалу дослідження. Організаційно-економічний механізм розвитку є цілісним утворенням з чітко вираженою структурою - підсистемами, які iii формують за двома базовими блоками (організаційним й економічним), між якими налагоджена система стійких взаємозалежностей, тобто деструктивність

\section{Інформація про авторів:}

Свелеба Наталія Андріївна, канд. екон. наук, доцент, кафедра обліку і фінансів. Email: Olga_major@ukr.net Майор Ольга Володимирівна, канд. екон. наук, доцент, кафедра обліку і фінансів. Email: Olga_major@ukr.net

Цитування за ДстУ: Свелеба Н. А., Майор О. В. Податкові важелі впливу на формування організаційно-економічного механізму розвитку підприємств сфер послуг. Науковий вісник НЛтУ України. Серія Економічна. 2018, т. 28, № 4. С. $112-115$

Citation APA: Sveleba, N. A., \& Major, O. V. (2018). Tax Levers of Influence on the Formation of Organizational and Economic Mechanism for Development of Service Sector Enterprises. Scientific Bulletin of UNFU, 28(4), 112-115.

https://doi.org/10.15421/40280421 
однієї підсистеми спричиняє деструктивність іншої та, як наслідок - усього механізму, і навпаки.

Основним цільовим завданням формування та реалізації організаційно-економічного механізму розвитку підприємств сфери послуг є забезпечення якості надаваних послуг, наповнення бюджетів державного та місцевого рівнів, залучення зовнішніх інвестицій, підвищення попиту на послуги, збільшення зайнятості населення та підвищення якості внутрішньої інфраструктури.

Функціонування організаційно-економічного механізму розвитку підприємств сфери послуг включає поєднання двох складників: 1) організаційного, що передбачає формування системи різних інститутів, що мають організаційний вплив на суб'єкти діяльності та суміжні сектори економіки; 2) економічного - податкова система, фінансова політика, інвестиційна діяльність тощо. Загальний вигляд схеми представлено на рис. 1.

\begin{tabular}{|c|c|c|}
\multicolumn{2}{|c|}{ Організаційно-економічний механізм розвитку } \\
Цоідприств сфери послуг
\end{tabular}

Рис. 1. Організаційно-економічний механізм розвитку підприємств сфери послуг

На сьогодні українські підприємства сфери послуг, що в основному представлені суб'єктами малого та середнього бізнесу, поставлено в досить жорсткі умови виживання. Аналіз загального середовища та тенденцій у сфері регулювання малого бізнесу свідчить, що найвагомішим чинником обмеження розвитку малого бізнесу $є$ істотний адміністративно-податковий тиск (Danylyshyn, Koretsьkyi \& Datsii, 2006, p. 142).

Складність оподаткування підприємництва в Україні організаційного характеру криється в необхідності витрачання значного часу на здійснення обліку, нарахування та сплату податків, проходження перевірок, здачу звітів. Попри значні витрати часу вітчизняні підприємці стикаються зі складністю, іноді неоднозначністю трактування податкового законодавства (Kodeks, 2010).

Неефективність чинної системи оподаткування малого бізнесу в Україні та недоліки податкового механізму підтверджують дані рейтингу Світового банку Doing Business-2017, згідно з яким Україна посідає 107 місце серед 190 країн та 76 місце щодо легкості ведення бізнесу (Doing Business, 2016).

Дорожню карту змін механізмів оподаткування потрібно будувати 3 огляду на ранжування найголовніших проблем оподаткування, серед яких: нестабільність податкового законодавства, високе податкове навантаження, складне та непрозоре податкове адміністрування, що слугує дестимулятором розвитку підприємництва в Україні, тіньова економіка, зависокі ставки прямих податків, висока частка контрабандної продукції на ринку, нерівномірне податкове навантаження на бізнес, складність i непрозорість процедур відшкодування ПДВ, відсутність довготермінової передбаченої акцизної політики (Kondratenko, 2015, p. 15).

Враховуючи перелічену низку проблем, суб'єктам господарювання потрібно серйозно підійти до вибору та використання податкових важелів впливу на організаційно-економічний механізм підприємства для забезпечення ефективності його функціонування. Серед таких важелів варто виокремити податкові інструменти, які передбачають оптимізацію кількості податків для підприємств сфери послуг, надання податкового кредиту, податкових пільг під конкретні проекти, які спрямовані на вирішення регіональних і соціальних проблем, розвитку соціального підприємництва, інвестування у діяльність, вибір альтернативних форм оподаткування (спрощеної), використання податкового менеджменту як засобу оптимізації податкових платежів.

На сьогодні найважливішою формою державної підтримки підприємств сфери послуг як малого бізнесу в Україні є спрощена система оподаткування, яка передбачає заміну встановлених державою податків і зборів сплатою єдиного податку та застосування спрощеної форми бухгалтерського обліку та звітності (Klepanchuk, 2014 , p. 28). Застосування спрощеної форми оподаткування забезпечує отримання економічних ефектів як на мікро-, так і макрорівнях (рис. 2).

На мікрорівні вплив спрощеного оподаткування на малий бізнес здійснюється у двох напрямах - ресурсному та поведінковому. Ефект у ресурсному вимірі - це зменшення податкового навантаження, як наслідок вивільнення ресурсів для розвитку, спрощення процедур звітності, як наслідок, зменшення ризику корупції.

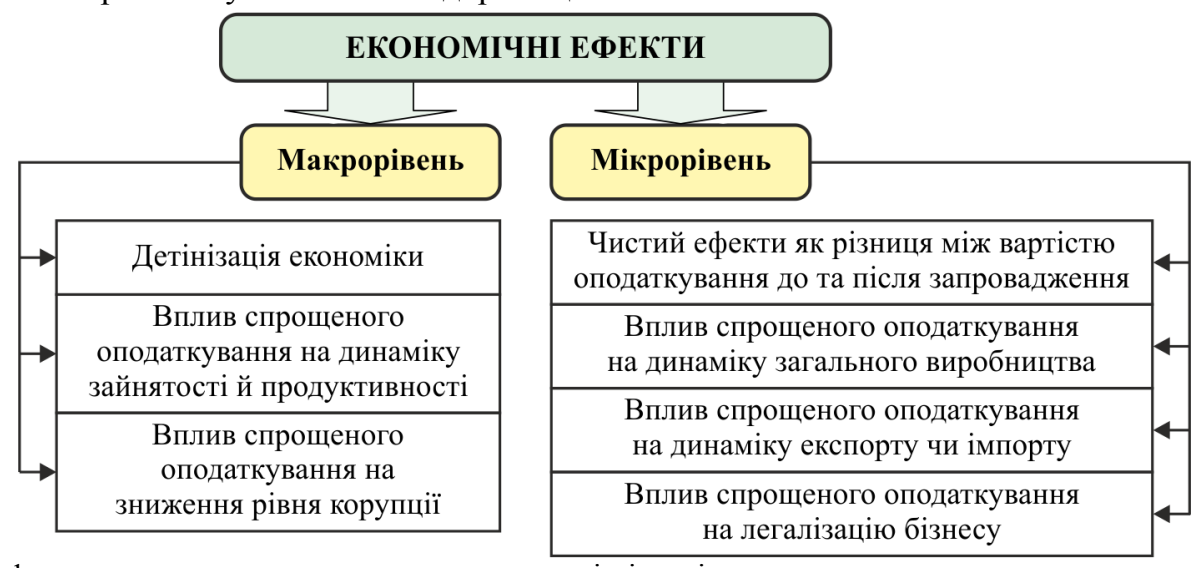

Рис. 2. Економічні ефекти спрощеного оподаткування на макро- і мікрорівнях 
Щодо поведінкового ефекту, то зменшення вартості оподаткування за інших рівних умов стимулюватиме створення нових та сприятиме активізації розвитку діючих підприємств сфери послуг.

В Україні вже не один рік тривають дискусії щодо шляхів реформування спрощеної системи оподаткування малого підприємництва. Деякі фахівці пропонують взагалі скасувати спрощену систему оподаткування, інші ж, навпаки, зберегти наявний порядок спрощеного оподаткування та розширити перелік суб'єктів малого підприємництва, на яких поширюється дія спрощеної системи оподаткування. На нашу думку, доцільним $є$ збереження спрощеної системи оподаткування діяльності підприємств сфери послуг, як такої з обов'язковим iii удосконаленням та модернізацією відповідно до сучасних умов господарювання, а саме:

- узгодження принципів бухгалтерського і податкового обліку для уніфікації фінансових показників та ідентифікації документальних носіїв інформації;

- зменшення податкових платежів, що відносяться на собівартість, відповідно деформуючи структуру виробничого споживання;

- попередження фактів вилучення оборотного капіталу на погашення податкової заборгованості шляхом оптимізації об'єктів оподаткування та реальних джерел їх сплати;

- спрощення процедур податкового менеджменту, спрямованих на скорочення витрат на податкове адміністрування;

- періодизація податкових зобов'язань і термінів їх виконання перед бюджетом згідно з датами виникнення джерел сплати того чи іншого податку.

Актуальною для всіх платників є проблема легальної мінімізації податкових платежів, однак особливого значення вона набуває для суб'єктів підприємницької діяльності з обмеженими фінансовими можливостями.

Вихідним інструментом податкового механізму податкових платежів $є$ податковий менеджмент, що, водночас, включає низку взаємопов'язаних, логічно послідовних фіскальних дій і процесів. Ефективна система податкового менеджменту в організаціях здатна виступити інструментом взаємоузгодження різнопланових управлінських функцій та процесів.

Згідно $з$ тенденціями щодо розвитку податкового менеджменту в Україні складниками системи податкового менеджменту підприємств сфери послуг повинні стати такі:

- стратегія оптимізації податкових зобов'язань із чітким планом іiі реалізації;

- формування облікової політики для оподаткування, спрямованої на максимальне використання можливостей для зниження податкового тягаря, передбачених податковим законодавством України, які розробляють 3 урахуванням зовнішніх і внутрішніх чинників;

- планування раціонального розміщення активів не тільки 3 погляду прибутковості інвестицій, але і розмірів податків, що сплачуються при отриманні доходів;

- оптимізація договірних відносин із контрагентами через вибір типу договору, партнера з бізнесу й умов операції. Договори ЦПХ, аутстафінг та аутсорсинг тільки здаються незнайомими та новими термінами. За договором ЦПХ фрілансер може розробити сайт, аутстафінгова компанія може надати персонал для підтримання чистоти в торговельному залі. Аутсорсингова компанія може професійно супроводжувати вашу невеличку комп'ютерну мережу, управляти рекламними кампаніями або вести облік, забезпечувати оптимізацію податкових платежів;
- визначення і моніторинг пільг, що діють у поточному і подальшому податкових періодах, якими має право користуватися підприємство;

- застосування обгрунтованих і ефективних методик розподілу непрямих витрат, що дають змогу зменшити податкові платежі;

- розроблення системи контролю за наднормативними витратами, що не враховуються для оподаткування;

- податковий операційний моніторинг господарювання (діагностика витратної політики підприємства, податковий експрес-аналіз інноваційно-інвестиційних проектів, договорів, контрактів співпраці з партнерами);

- застосування у практичній діяльності суб'єктів сфери послуг податкового аналізу, оцінювання впливу податків на формування результатів діяльності, оцінювання ефективності використання схем оптимізації оподаткування та податкового навантаження;

- для удосконалення обліково-інформаційного забезпечення прийняття управлінських рішень щодо оптимізації оподаткування ввести регістр податкового обліку - податковий паспорт як сукупність відомостей про діяльність суб'єктів господарювання.

Висновки. Розвиток малого бізнесу в Україні $є$ icтотним недовикористаним резервом економічного зростання. Його активізація є одним із ключових пріоритетів регулювання соціально-економічного розвитку економіки України.

Вихідним інструментом налагодженого механізму податкових платежів $є$ податковий менеджмент, що, водночас, включає низку взаємопов'язаних, логічно послідовних фіскальних дій і процесів: аналіз зовнішнього податкового середовища, податкове прогнозування, поточне податкове планування, податковий моніторинг фінансово-господарських операцій, податковий облік і звітність, податковий контроль, забезпечення внутрішніх і зовнішніх податкових взаємозв'язків, оцінювання отриманих управлінських результатів. Серед проблем раціонального управління податковими відносинами та їх матеріальним втіленням - обсягами податкових зобов'язань - можна виділити суперечливість норм податкового законодавства, невизначеність пріоритетів і засад фіскальної політики, недостатню емпіричну основу податкових рішень, істотний рівень тінізації економіки з характерною для нього відсутністю бізнесової етики й податкової дисципліни, домінування адміністративних управлінських тенденцій.

\section{Перелік використаних джерел}

Danylyshyn, B. M., Koretskyi, M. Kh., \& Datsii, O. I. (2006). Investytsiina polityka v Ukraini: monohrafiia. Donetsk: Vyd-vo "Yuho-Vostok, Ltd". 292 p. [In Ukrainian].

Doing Business. (2016). Data and Rankings. The World Bank Group.

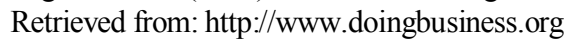

Klepanchuk, O. Yu. (2014). Priami ta oposerdkovani formy fiksalnoho vplyvu na rozvytok maloho biznesu. Informatsiine suspilstvo: tekhnolohichni, ekonomichni ta tekhnichni aspekty stanovlennia: mater. Vseukr. nauk. internet-konferentsiia, 7, 25-30. Ternopil: Vyd-vo Ternopil. NEU Ukrainy. [In Ukrainian].

Kodeks. (2010). Podatkovyi kodeks Ukrainy vid 02.12.2010 r., № 2755-VI. Retrieved from: http://zakon5.rada.gov.ua/laws/show/2755-17. [In Ukrainian].

Kondratenko, M. B. (2015). Podatkove navantazhennia ta shliakhy yoho optymizatsii v Ukraini. Abstract of Candidate Dissertation for Economic Sciences (08.00.08 - Money, Finance and Credit). Kyiv. 22 p. [In Ukrainian]. 


\section{НАЛОГОВЫЕ РЫЧАГИ ВЛИЯНИЯ НА ФОРМИРОВАНИЕ ОРГАНИЗАЦИОННО- ЭКОНОМИЧЕСКОГО МЕХАНИЗМА РАЗВИТИЯ ПРЕДПРИЯТИЙ СФЕРЫ УСЛУГ}

Рассмотрен организационно-экономический механизм развития предприятий сферы услуг, выделены его составляющие. Выявлены основные подходы к организации налогообложения предприятий сферы услуг в контексте стимулирования их развития, которые требуют углубленного изучения и научного обоснования действующих методик взимания налогов в предпринимательской деятельности. Определены основные задачи формирования и реализации организационно-экономического механизма развития предприятий сферы услуг, среди которых: обеспечение качества предоставляемых услуг, пополнение бюджетов государственного и местного уровней, привлечение внешних инвестиций, повышение спроса на услуги, увеличение занятости населения и повышение качества внутренней инфраструктуры. Определено, что сложность налогообложения предпринимательства в Украине организационного характера кроется в необходимости расходования значительного времени на осуществление учета, начисления и уплаты налогов, прохождение проверок, сдачу отчетов. Предложено субъектам хозяйствования использование налоговых рычагов влияния на организационно-экономический механизм предприятия. Среди таких рычагов можно выделить налоговые инструменты, которые предусматривают оптимизацию количества налогов для предприятий сферы услуг, предоставление налогового кредита, налоговых льгот конкретные проекты, направленные на решение региональных и социальных проблем, развития социального предпринимательства, инвестирования в деятельность, выбор альтернативных форм налогообложения (упрощенной), использование налогового менеджмента как средства оптимизации налоговых платежей (оптимизацию договорных отношений, применение обоснованных и эффективных методик распределения косвенных расходов, позволяющие уменьшить налоговые платежи, разработка системы контроля за сверхнормативные расходы, не учитываемые в целях налогообложения; налоговый операционный мониторинг хозяйствования, диагностика расходной политики предприятия, налоговый экспресс-анализ инновационно-инвестиционных проектов).

Ключевые слова: налоги; системы налогообложения; налоговая нагрузка; налоговый паспорт; оптимизация налоговых обязательств; налоговый мониторинг.

N. A. Sveleba, O. V. Major

Lviv Institute of Economy and Tourism, Lviv, Ukraine

\section{TAX LEVERS OF INFLUENCE ON THE FORMATION OF ORGANIZATIONAL AND ECONOMIC MECHANISM FOR DEVELOPMENT OF SERVICE SECTOR ENTERPRISES}

The authors have considered organizational and economic mechanism of development of service sector enterprises. We have distinguished its components. The basic approaches to organization of taxation of service sector enterprises in the context of stimulating their development, which require in-depth study and scientific substantiation of the current methods of tax collection in entrepreneurial activity, are revealed. The main tasks of the formation and implementation of the organizational and economic mechanism of development of service enterprises are defined, among them are as follows: quality assurance of the services provided; replenishment of budgets of the state and local levels; attraction of external investments; increase of demand for services; increase of population employment; and improvement of the quality of the internal infrastructure. We have determined that the complexity of the taxation of entrepreneurship in Ukraine of an organizational nature is in the need to spend a considerable amount of time on accounting, tax assessment and payment, inspections, and reporting complexity, and ambiguity in the interpretation of tax legislation. We suggested economic entities to use the tax levers of influence on the organizational and economic mechanism of the enterprise among such instruments it is necessary to distinguish tax instruments that provide optimization of the amount of taxes for enterprises of the service sector, the provision of a tax credit, tax benefits for specific projects aimed at resolving regional and social problems, the development of social entrepreneurship, investing in activities, the choice of alternative forms of taxation (simplified), use of tax management as a means of optimizing tax payments (optimization of contractual relations, application of reasonable and effective methods of distribution of indirect costs, allowing to reduce tax payments; development of a system of control over over-regulatory costs that are not taken into account for tax purposes; tax operational monitoring of management, diagnostics of cost policy of the enterprise, tax express analysis of innovation and investment projects).

Keywords: taxes; tax systems; tax burden; tax passport; optimization of tax liabilities; tax monitoring. 